\title{
Kandungan Air Daun Padi Lokal Sulut pada Fase Vegetatif saat Mengalami Rendaman dan Kekurangan Air (Leaf Water Content of North Sulawesi Local Rice at the Vegetative Phase under Waterlogging and Water Deficit Condition)
}

\author{
Marlince Koda ${ }^{1)}$, Nio Song $A i^{1)^{*}}$, Parluhutan Siahaan ${ }^{1)}$ \\ 1)Program Studi Biologi, Jurusan Biologi FMIPA UNSRAT Manado, 95115 \\ "Email korespondensi: niosongai@unsrat.ac.id
}

Diterima 25 Januari 2017, diterima untuk dipublikasikan 20 Februari 2017

\begin{abstract}
Abstrak
Penelitian telah dilakukan untuk mengkaji kandungan air daun sebagai salah satu respon fisiologi pada tanaman padi lokal Sulawesi Utara (Superwin, Ombong, Temo dan Burungan) pada fase vegetatif saat mengalami perlakuan rendaman dan kekurangan air. Tanaman tidak disiram dengan air selama 14 hari pada perlakuan kekurangan air. Tanaman dalam pot dimasukkan ke dalam bak air yang berisi air dengan tinggi rendaman $15 \mathrm{~cm}$ di atas permukaan media selama 14 hari pada perlakuan rendaman. Kandungan air daun berbeda antar varietas dan antar perlakuan, tetapi interaksi antara faktor varietas dan faktor perlakuan cekaman tidak menyebabkan perbedaan kandungan air daun yang nyata. Kandungan air daun terendah diamati pada varietas Superwin $(0,78 \mathrm{mg} / \mathrm{L})$, sedangkan kandungan air daun yang tertinggi diamati pada varietas Ombong $(0,89$ $\mathrm{mg} / \mathrm{L})$. Kandungan air daun pada keempat varietas padi berturut-turut dari yang terendah ke yang tertinggi adalah pada perlakuan kekurangan air (0,79 mg/L), kontrol (0,84 $\mathrm{mg} / \mathrm{L})$ dan rendaman $(0,90 \mathrm{mg} / \mathrm{L})$.

Kata kunci: kandungan air daun, kekurangan air, padi lokal Sulut, rendaman, vegetatif
\end{abstract}

\begin{abstract}
A study was carried out to evaluate leaf water content as one of the physiological responses in the North Sulawesi Utara local rice (Superwin, Ombong, Temo and Burungan) at the vegetative phase under waterlogging and water deficit condition. When treatments commenced, water was withheld from water-deficit plants and the water level was $15 \mathrm{~cm}$ above the waterlogged plants. Leaf water content was different among varieties and among treatments, but the interaction between varieties and treatments did not result in significantly different leaf water content. The smallest leaf water content was observed in Superwin $(0.78 \mathrm{mg} / \mathrm{L})$, whereas the largest leaf water content was in Ombong $(0.89 \mathrm{mg} / \mathrm{L})$. Leaf water content in these four rice varieties from the lowest to the highest was in the treatments of water deficit $(0.79 \mathrm{mg} / \mathrm{L})$, well-watered $(0.84 \mathrm{mg} / \mathrm{L})$ and waterlogging (0.90 mg/L), respectively.

Keywords: leaf water content, North Sulawesi Utara local rice, water deficit, waterlogging, vegetative

\section{PENDAHULUAN}

Indonesia merupakan salah satu negara yang banyak dilanda bencana alam, di antaranya bencana kebanjiran dan kekeringan (BNPB

2013). Peristiwa banjir ini terjadi karena kondisi curah hujan yang ekstrim. Curah hujan dalam kondisi normal dapat menjamin ketersediaan air bagi pertumbuhan padi sawah,
\end{abstract}


akan tetapi ketersediaan air yang berlebih bisa mengakibatkan tanaman terendam. Ketidakmampuan tanaman untuk bertahan dalam kondisi oksigen yang rendah di daerah perakaran telah menyebabkan banyak kerugian akibat ketidakberhasilan tanaman untuk berproduksi. Pada lahan rawa, curah hujan yang tinggi menyebabkan periode rendaman menjadi lebih lama dan hal ini menyebabkan tidak hanya waktu awal musim tanam menjadi terganggu, tetapi juga dapat menyebabkan tanaman di lapang menjadi terendam (Dennis et al. 2000). Kondisi seperti inilah yang dikhawatirkan karena dapat menyebabkan terjadinya penurunan produksi padi (Boer 2010). Cekaman rendaman menyebabkan tanaman menjadi kekurangan $\mathrm{O}_{2}$ dan $\mathrm{CO}_{2}$, sehingga menghambat respirasi serta menghambat terjadinya fotosintesis. Kondisi ini mengakibatkan tumbuhan kekurangan energi untuk tumbuh dan berkembang. Biasanya tanaman padi yang masih muda lebih rentan terhadap cekaman rendaman (Jackson dan Ram 2003).

Tanaman padi di Indonesia tidak hanya menghadapi tantangan cekaman rendaman, tetapi juga cekaman kekurangan air. Kekurangan air yang ekstrim disebut dengan cekaman kekeringan. Kekurangan air mempengaruhi semua aspek pertumbuhan tanaman, yang meliputi proses fisiologi, biokimia, anatomi dan morfologi. Kekurangan air berpengaruh terhadap kandungan air daun. Durasi kekurangan air juga mengakibatkan penurunan potensial air daun, kadar air daun, dan kandungan air daun relatif (Bramasto et al. 2015). Sulawesi Utara memiliki beberapa varietas padi lokal, di antaranya varietas Superwin, Ombong, Temo, dan Burungan. Data tentang kemampuan tumbuhan ini dalam merespon cekaman rendaman dan cekaman kekurangan air yang ditinjau dari respon fisiologis, seperti kandungan air daun masih kurang. Penelitian untuk mengkaji respon fisiologi tanaman padi lokal Sulut yang mengalami rendaman dan kekurangan air selama 14 hari dilakukan pada fase vegetatif berdasarkan kandungan air daun.

\section{METODE}

Penelitian ini dilaksanakan selama 9 minggu di rumah kaca di Kelurahan Tingkulu, Manado, Sulawesi Utara dan Laboratorium Ekologi Jurusan Biologi FMIPA Universitas Sam Ratulangi. Bahan yang digunakan dalam penelitian ini adalah padi lokal Sulawesi Utara, yaitu varietas Superwin, Ombong, Temo dan Burungan.

Tahapan kerja dalam penelitian ini meliputi seleksi benih, perkecambahan benih, pemeliharaan tanaman, perlakuan rendaman dan kekurangan air, dan pengambilan sampel daun. Seleksi benih dilakukan dengan cara benih direndam di dalam air garam selama 2 jam dengan tujuan untuk mendapatkan benih yang berkualitas. Benih padi disterilisasi dengan menggunakan pemutih komersial $2 \%$ selama 2 menit dengan 3 kali ulangan, kemudian dicuci dengan air yang sudah dimasak. Sebelum penanaman, tiap pot yang telah berisi media (tanah:sekam:pupuk kandang = 5:1:1 dan ditambahkan pupuk NPK dengan konsentrasi $6 \mathrm{~g}$ pupuk NPK tiap $7 \mathrm{~kg}$ tanah) disiram dengan air sampai kapasitas lapang. Selanjutnya benih ditanam pada media di botol air mineral $1.500 \mathrm{~mL}$ (3 benih di tiap pot), dan bagian atas wadah ditutup dengan kantong plastik yang sudah dibasahi (modifikasi Nio dan Ludong 2013). 
Pada saat benih yang ditanam pada media dalam pot botol air mineral telah tumbuh, dipilih 1 tanaman pada tiap pot, selanjutnya tanaman tersebut dipelihara dengan cara disiram dengan campuran air dan pupuk (10 g pupuk Gandasil D dalam $10 \mathrm{~L}$ air) sampai kapasitas lapang setiap 2 hari. Penyiraman tanaman sampai kapasitas lapang terus dilakukan sampai tanaman mencapai tahap 4 daun yang berkembang penuh atau 4 fully expanded leaf dan perlakuan dimulai selama 14 hari (Nio and Ludong 2013). Tanaman yang diberi perlakuan kekurangan air tidak disiram dengan air. Pada perlakuan rendaman, tanaman dalam pot dimasukkan ke dalam bak air yang berisi air, sampai tanaman terendam $15 \mathrm{~cm}$ di atas permukaan media selama 14 hari. Tanaman padi kontrol disiram dengan air saja (tanpa pupuk) sampai kapasitas lapang tiap 2 hari sekali. Temperatur dan kelembaban udara di rumah kaca selama penelitian berlangsung ialah $23-41^{\circ} \mathrm{C}$ dan $29-87 \%$.

Pengambilan sampel daun dilakukan 14 hari setelah perlakuan cekaman banjir dan kekeringan pada padi varietas Superwin, Ombong, Temo dan Burungan. Sampel daun yang akan digunakan untuk penentuan kandungan air daun ialah daun termuda pada urutan kedua dari pucuk tiap tanaman dalam pot. Sampel daun dimasukkan ke dalam kantong plastik secara terpisah, lalu disimpan dalam wadah plastik yang telah berisi es batu dan segera dibawa ke laboratorium untuk dianalisis kandungan air daun. Penentuan berat segar (BS) daun dengan memotong daun ukuran $1 \times 1$ $\mathrm{cm}$ pada semua varietas, memasukkannya ke dalam botol timbang kemudian menimbangnya. Berat kering daun diperoleh dengan cara memasukkan semua potongan daun tadi ke dalam wadah plastik berpenutup yang telah berisi larutan $\mathrm{CaSO}_{4} 0,5 \mathrm{mM}$, lalu menutupnya dan meletakkannya di tempat gelap selama 1 x 24 jam. Semua potongan daun diletakkan dalam oven kering pada suhu $70^{\circ} \mathrm{C}$ selama 48 jam dan ditimbang berat keringnya (BK). Kandungan air daun $(\mathrm{mL} / \mathrm{g}$ berat kering) ditentukan dengan rumus = (BS-BK)/BK (Nio et al. 2011).

\section{HASIL DAN PEMBAHASAN}

Air merupakan faktor utama dalam proses fisiologi tanaman, sehingga tanaman tidak akan bertahan lama jika tidak mendapatkan pasokan air yang cukup. Kandungan air daun pada keempat varietas padi Sulut lokal setelah perlakuan rendaman dan kekurangan air ditunjukkan pada Tabel 1. Analisis sidik ragam menunjukkan bahwa kandungan air daun berbeda antar varietas (Tabel 2) dan antar perlakuan (Tabel 3), tetapi interaksi antara faktor varietas dan faktor perlakuan cekaman tidak menyebabkan perbedaan kandungan air daun yang nyata. Uji lanjut dengan Bukti Nyata Terkecil (BNT) 5\% menunjukkan bahwa kandungan air daun terendah diamati pada varietas Superwin $(0,78 \mathrm{~mL} / \mathrm{g}$ berat kering), sedangkan kandungan air daun yang tertinggi diamati pada varietas Ombong $(0,89 \mathrm{~mL} / \mathrm{g}$ berat kering). Kandungan air daun pada keempat varietas padi berturut-turut dari yang terendah ke yang tertinggi adalah pada perlakuan kekurangan air $(0,79 \mathrm{~mL} / \mathrm{g}$ berat kering), kontrol $(0,84 \mathrm{~mL} / \mathrm{g}$ berat kering) dan rendaman $(0,90 \mathrm{~mL} / \mathrm{g}$ berat kering $)$. 
Tabel 1. Kandungan air daun ( $\mathrm{mL} / \mathrm{g}$ berat kering) padi varietas Superwin, Ombong, Temo, dan Burungan pada kondisi kontrol, rendaman dan kekurangan air $(n=10)$

\begin{tabular}{cccc}
\hline & \multicolumn{3}{c}{ Rata-rata \pm SE } \\
\cline { 2 - 4 } Varietas & Kontrol & Rendaman & Kekurangan air \\
\hline Superwin & $0,80 \pm 0,02$ & $0,78 \pm 0,02$ & $0,76 \pm 0,01$ \\
Ombong & $0,84 \pm 0,04$ & $0,99 \pm 0,05$ & $0,82 \pm 0,01$ \\
Temo & $0,82 \pm 0,03$ & $0,87 \pm 0,04$ & $0,80 \pm 0,01$ \\
Burungan & $0,88 \pm 0,04$ & $0,95 \pm 0,04$ & $0,78 \pm 0,01$ \\
\hline
\end{tabular}

Keterangan: SE = standar eror

Tabel 2. Kandungan air daun ( $\mathrm{mL} / \mathrm{g}$ berat kering) pada varietas-varietas padi lokal Sulut $(n=10)$

\begin{tabular}{cc}
\hline Varietas & Rata-rata \pm SE \\
\hline Superwin & $0,78 \pm 0,01^{\mathrm{a}}$ \\
Ombong & $0,89 \pm 0,03^{\mathrm{d}}$ \\
Temo & $0,83 \pm 0,02^{\mathrm{b}}$ \\
Burungan & $0,87 \pm 0,02^{\mathrm{c}}$
\end{tabular}

Keterangan: huruf yang berbeda di belakang angka rata-rata menunjukkan ada perbedaan yang nyata pada taraf $5 \%$. SE $=$ standar eror

Tabel 3. Kandungan air daun $(\mathrm{mL} / \mathrm{g}$ berat kering) pada kondisi kontrol, rendaman dan kekurangan air padi lokal Sulut $(n=10)$

\begin{tabular}{cc}
\hline Kondisi & Rata-rata \pm SE \\
\hline Kontrol & $0,84 \pm 0,02^{\mathrm{b}}$ \\
Rendaman & $0,90 \pm 0,02^{\mathrm{c}}$ \\
Kekurangan air & $0,79 \pm 0,01^{\mathrm{a}}$
\end{tabular}

Keterangan: huruf yang berbeda di belakang angka rata-rata menunjukkan ada perbedaan yang nyata pada taraf $5 \%$. SE $=$ standar eror

Hasil yang sama juga ditunjukkan pada tanaman kelapa sawit (Elaeis guineensis Jacq.) dengan perlakuan cekaman kekeringan. Cekaman kekeringan berpengaruh nyata terhadap kandungan air daun. Tanaman yang diberi cekaman kekeringan mengalami penurunan kandungan air daun sejak hari ke-7 dan hari ke-14 (Mathius et al. 2001). Kandungan air daun gandum varietas Hartog dan Sunco yang mengalami kekeringan lebih kecil daripada yang diairi sampai kapasitas lapang (Nio et al. 2011). Semakin lama tanaman mengalami perlakuan kekurangan air, maka semakin berkurang kandungan air daun. Tanaman merespon kekurangan air dengan mengurangi laju transpirasi untuk penghematan air. Kekurangan air pada daun akan menyebabkan selsel tanaman kehilangan turgor. Mekanisme yang dapat memperlambat laju transpirasi atau menurunkan dampak kehilangan air adalah dengan cara menutup stomata, dan memperkecil luas permukaan daun dengan penggulungan daun (Fischer dan Fukai 2003).

\section{KESIMPULAN}

Respon fisiologi tanaman padi lokal Sulut (varietas Superwin, Ombong, Temo, dan Burungan) yang 


mengalami rendaman
kekurangan air selama 14 hari
dievaluasi pada fase vegetatif
berdasarkan kandungan air daun.
Kandungan air daun padi lokal
Sulawesi Utara yang terendah
diamati pada varietas Superwin,
sedangkan kandungan air daun yang
tertinggi diamati pada varietas
Ombong. Kandungan air daun
keempat varietas padi pada
perlakuan rendaman lebih besar
daripada kekurangan air dan diairi
sampai kapasitas lapang.

\section{DAFTAR PUSTAKA}

BNPB (2013) Laporan Pusdalops. BNPB, Jakarta

Boer R, Buono A, Suciantini (2010) Pengembangan kalender tanaman dinamik sebagai alat dalam menyesuaikan pola tanam dengan prakiraan iklim musiman. Laporan Hasil Penelitian I-MHERE B2CIPB, Bogor

Bramasto Y, Rustam E, Megawati, Mindawati N (2015) Respon pertumbuhan bibit bawang lanang (Michelia champaca L.) terhadap cekaman. Jurnal Penelitian Hutan Tanaman 12(3): 211-221

Dennis ES, Dolferus R, Ellis M, Rahman M, Wu Y, Hoeren FU, Grover A, Ismond KP, Good AG, Peacock WJ (2000) Molecular strategies for improving waterlogging tolerance in plants. J Exp Bot 51(342): 89-97

Fischer KS, Fukai S (2003) How rice responds to drought. Dalam: Fischer KS, Lattife R, Fukai S,
Atlin G, Hardy B (Eds)

Breeding rice for drought prone enviroments.

International Rice Research Institute, Los Banos, Philippines

Jackson MB, Ram PC (2003) Physiological and molecular basis of susceptibility and tolerance of rice plants to complete submergence. Ann Bot $91: 227-241$

Mathius NT, Wijana G, Guharja E, Aswidinnoor $\mathrm{H}$, Yahya $\mathrm{S}$, Subronto (2001) Respon tanaman kelapa sawit (Elaneis guineensis Jacq) terhadap cekaman kurang air. Menara Perkebunan 69(2): 29-45

Nio SA, Ludong DPM (2013) Comparing the drought tolerance of local rice cultivar Superwin with other cultivar in North Sulawesi Province based on dry matter partitioning. 4th International Conference on Global Resource Conservation and 10th Indonesian Society for Plant Taxonomy Congress:"Plant Diversity for Food Security, Welfare and Harmony. Universitas Brawijaya. Malang. 7-8 Februari 2013.

Nio SA, Cawthray GR, Wade LJ, Colmer TD (2011) Pattern of solutes accumulated during leaf osmotic adjustment as related to duration of water for wheat at the reproductive stage. Plant Physiol and Biochem 49:1126-1137 